\title{
Complication and management of implant-assisted removable partial denture with distal extension: a clinical report
}

\author{
Jung-Yun Choi', Jung-Jin Lee ${ }^{1}$, Kwang-Yeob Song', Ju-Mi Park', Kyoung-A Kim², Jae-Min Seo* \\ 'Department of Prosthodontics, Institute of Oral Bio-Science, School of Dentistry, Chonbuk National University and Research \\ Institute of Clinical Medicine of Chonbuk National University-Biomedical Research Institute of Chonbuk National University \\ Hospital, Jeonju, Republic of Korea \\ ${ }^{2}$ Department of Dentistry, School of Medicine, Eulji University, Daejeon, Republic of Korea
}

Implant supported removable partial denture (ISRPD) using the implants enables favorable rehabilitation by complementing biomechanical limitations of the conventional removable partial denture (RPD). However, continuous recall check is necessary for evaluation of the mechanical and biological complications to ensure good long-term prognosis of ISRPD. This clinical report describes the complication and management in patient of Kennedy class I edentulism with ISRPD using healing abutment. The wear and fracture of healing abutment occurred at 36 months after delivery. So, healing abutment was replaced by connecting Locator ${ }^{\circledR}$ abutment for altering into the implant retained partial overdenture. (J Dent Rehabil Appl Sci 2016;32(4):338-44)

Key words: implant supported removable partial denture; locator; healing abutment; implant

\section{Introduction}

The differential displacement of the teeth and ridge causes a vertical and horizontal movement in the distal extended removable partial denture (DERPD). Because of the cantilever effect, destructive force is concentrated on the abutment teeth and alveolar ridge. ${ }^{1}$ In this case, implant supported removable partial denture (ISRPD) using implant placed in a biomechanically favorable strategic position can be alternative treatment. As additional support and retention with the implant can be obtained, it is effective for the Kennedy class I, II removable partial denture (RPD). ${ }^{2-4}$ Implant can be applied for support using healing abutment in ISRPD. And attachment

*Correspondence to: Jae-Min Seo

Associate Professor, Department of Prosthodontics, School of Dentistry and Institute of Oral Bio-Science, Chonbuk National University, 567, Baekje-daero, Deokjin-gu, Jeonju, 54896, Republic of Korea

Tel: +82-63-250-2696, Fax: +82-63-250-2218, E-mail: jmseo@jbnu.ac.kr

Received: September 7, 2016/Last Revision: December 12, 2016/Accepted:

December 17, 2016 can be connected to implant for retention and support in implant retained partial overdenture (IRPOD). ${ }^{5,6}$ Although several retrospective ISRPD studies have shown a high survival rate of implant, some mechanical complications can occur. de Freitas et al. ${ }^{7}$ reported that ISRPD had a high success rate ranging from $95-100 \%$ and good patient's satisfaction but showed several complications such as pitting of the healing abutment, replacement of resilient component of the attachment, damage in framework, screw loosening and damage in acrylic denture base.

This clinical report describes the mechanical complication of ISRPD. The patient with mandibular Kennedy class I edentulism was treated with ISRPD placed in the mandibular bilateral first molar area.

Copyright $(\mathrm{C} 2016$ The Korean Academy of Stomatognathic Function and Occlusion. (c) It is identical to Creative Commons Non-Commercial License. 
After 36 months for function, mechanical complications such as wear of healing abutment and screw fracture occurred. Subsequently, healing abutment was replaced with Locator ${ }^{\circledR}$ abutment.

\section{Case Report}

A 65-year-old female with pain of mandibular posterior edentulous ridge and discomfort due to mobility of DERPD, presented to the Department of Prosthodontics, Chonbuk National University Hospital. She had worn maxillary complete denture and mandibular DERPD for 6 years. These dentures showed poor retention, stability and excessive occlusal wear. Mandibular edentulous ridge showed moderate absorption equivalent to Class III edentulous area (Fig. 1). ${ }^{8}$ She had secondary caries on the right mandibular canine. Specific pathologic findings of jaws and temporomandibular joint were absent on radiographic examination.

An implant supported fixed partial denture was initially considered as a treatment option. However, due to refusal of extensive surgery and patients' economic status, maxillary complete denture and mandibular ISRPD with anterior surveyed prostheses were selected. At the initial visit, periodontal treatment was administered for anterior tooth improvement. After determining the implant position, ${ }^{9}$ computed tomography was taken with old RPD as radiographic stent. Two submerged-type implants (Bone level, RN

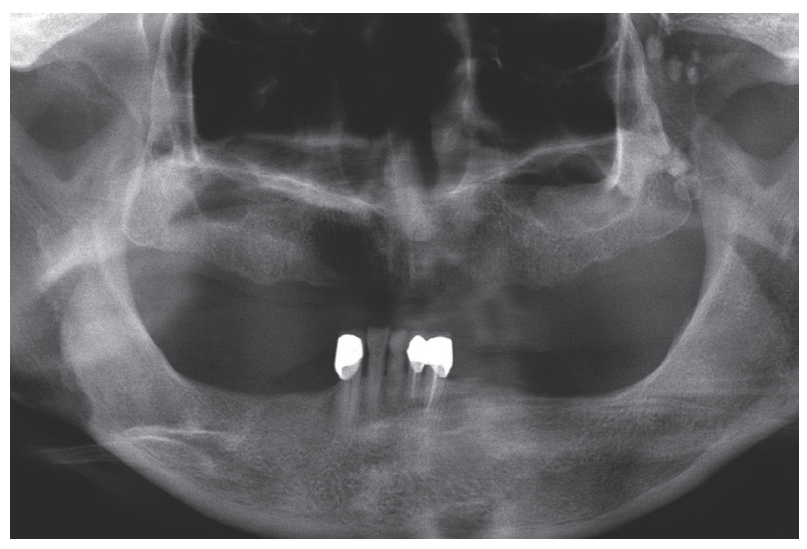

Fig. 1. Initial panoramic radiograph. crossfit $^{\circledR} ; 4.1 \times 8 \mathrm{~mm} / 4.8 \times 8 \mathrm{~mm}$, Straumann AG, Waldenburg, Switzerland) were placed on each left and right mandibular first molar area ${ }^{10}$ and healing abutment (6.5 $\mathrm{mm}$ in diameter, $6.0 \mathrm{~mm}$ in height) was connected, showing good initial stability (Fig. 2).

For two months after surgery, old dentures were relined with resilient material (COE-Soft ${ }^{\mathrm{TM}}$, GC Corp., Tokyo, Japan). Mandibular old restorations were removed and dental caries of right canine was treated. Surveyed metal ceramic restorations were fabricated and cemented to the mandibular left central incisor, lateral incisor and right canine (Fig. 3). Subsequently, mandibular ISRPD with linguoplate and wrought wire clasp was fabricated according to conventional procedure (Fig. 4). As the short implants were placed on the mandibular posterior area, the healing abutment was connected for support. Bilateral balanced occlusion was developed for stability of removable prostheses, the metal framework of the RPD was adjusted to minimum contact with the healing abutment of the implant and delivered (Fig. 5). The patient was instructed in hygiene procedures associated with the dentures and examined for fit and occlusion of prostheses after 24 hours. After 1 week, 4 weeks, 6 months and 12 months on the recall check, the patient was satisfied with esthetic and function of prostheses.

After 18 months of delivery, surface wear of the head of the healing abutment was observed at both sides (Fig. 6A). Metal framework of RPD were ad-

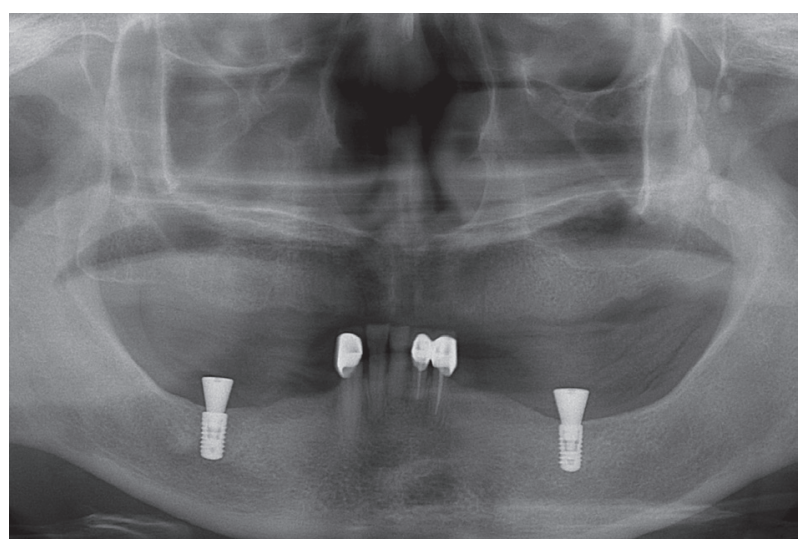

Fig. 2. Postoperative panoramic radiograph. Two short implants were placed in mandibular posterior area. 


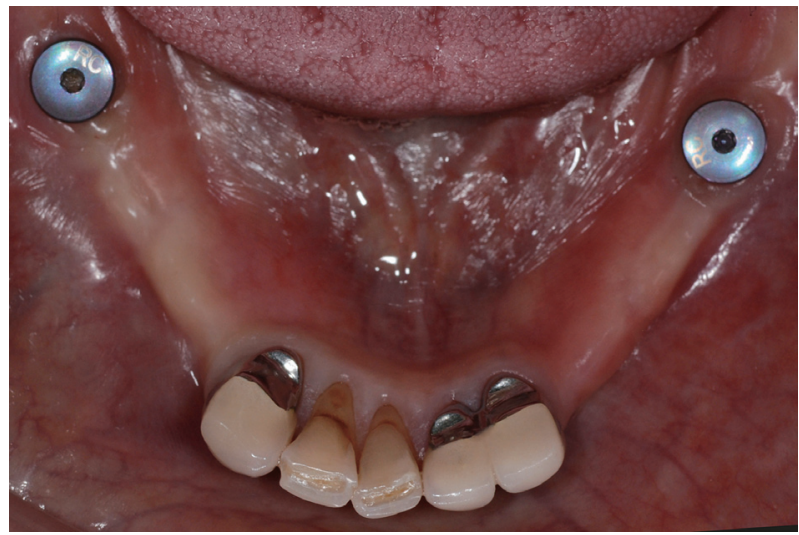

Fig. 3. Anterior surveyed prostheses were cemented. No inflammatory signs were observed around healing abutment.

justed to form the 1-point contact with healing abutment using pressure indicate paste (Fit Checker ${ }^{\mathrm{TM}}$, GC Corp.). At recall after 24 months, patient stated that mandibular dentures were loosened. As poor retention and stability were observed, a direct relining was performed with self-curing denture base resin (Rebase II, Tokuyama dental Corp., Tokyo, Japan). At recall after 30 months, no pathological findings were observed except wear of healing abutment (Fig. 6B).
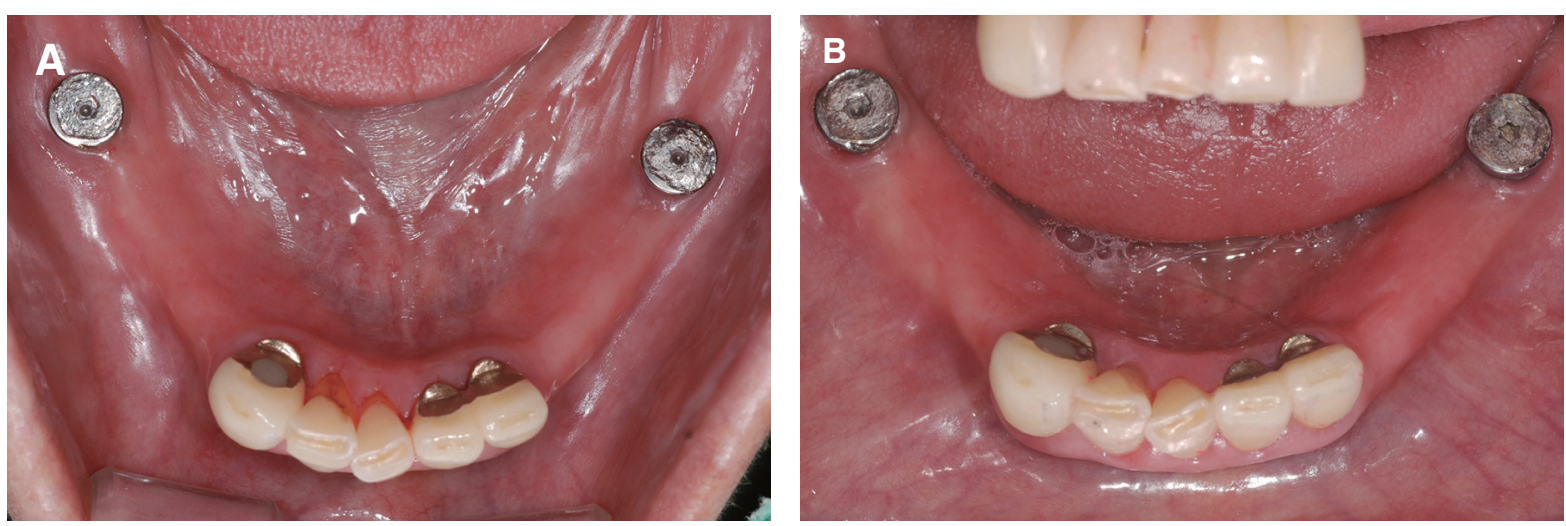

Fig. 6. (A) Occlusal view at 18 months after delivery. Mechanical wear was observed on flat surface of healing abutment, (B) At 30 months after delivery.

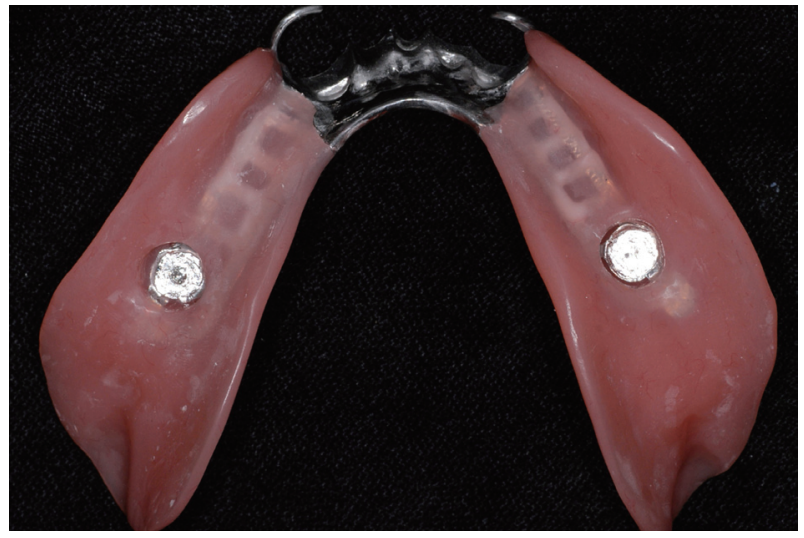

Fig. 4. Definitive removable partial denture was fabricated. Metal framework was adjusted to minimum contact with the healing abutment.

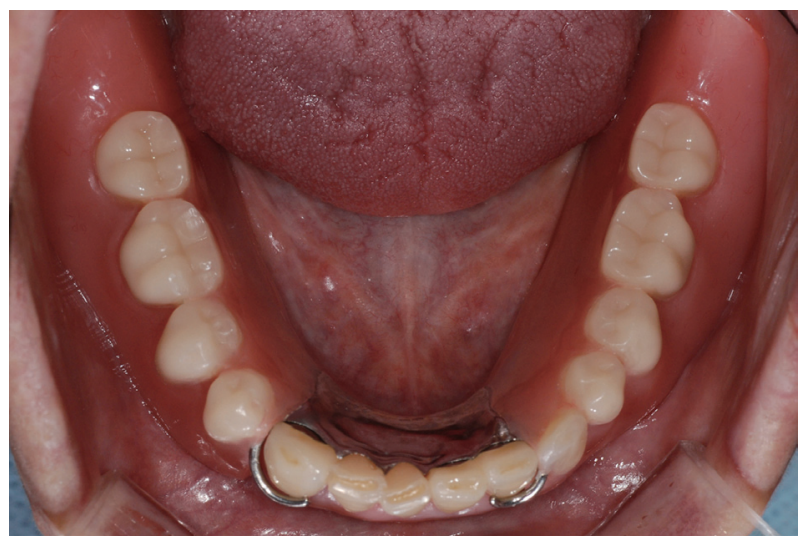

Fig. 5. Delivery of removable partial denture. 


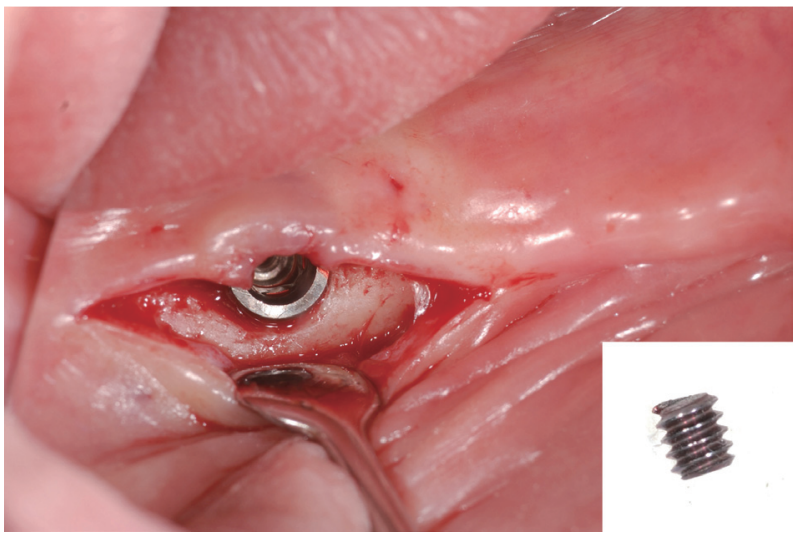

Fig. 7. Fragment of healing abutment was removed on mandibular right implant. Fracture of implant fixture was not observed.

After 36 months, patient experienced side to side rolling of the healing abutment due to fracture of the screw. No mobility or fracture of implant fixture was observed. So, only fragment of screw was removed (Fig. 7). Then, Locator ${ }^{\circledR}$ abutment (ZEST anchors LLC., Escondido, USA) with $4 \mathrm{~mm}$ gingival height was tightened to $30 \mathrm{Ncm}$ on both the implants. Metal housing was attached to existing ISRPD and blue nylon patrix was inserted (Fig. 8). Patient was satisfied with the retention and stability of IRPOD.

\section{Discussion}

A treatment plan for implant assisted removable partial denture (IARPD) requires consideration of diameter, length, position of the implant and the type of attachment. Cunha et al. ${ }^{9}$ reported that the amount of displacement of the denture was the smallest when implant was placed on the first molar region; Verri et al. ${ }^{10}$ strongly recommended the use of long and wide diameter implants because of favorable stress distribution. In this case, the healing abutments were connected to the implants placed in the area of the right and left mandibular first molars to provide additional support of the ISRPD.

Considering complications such as pitting corrosion of healing abutment, screw loosening and fractures, periodic recall appointments should be arranged. ${ }^{7,11}$ At 18 months recall appointment after

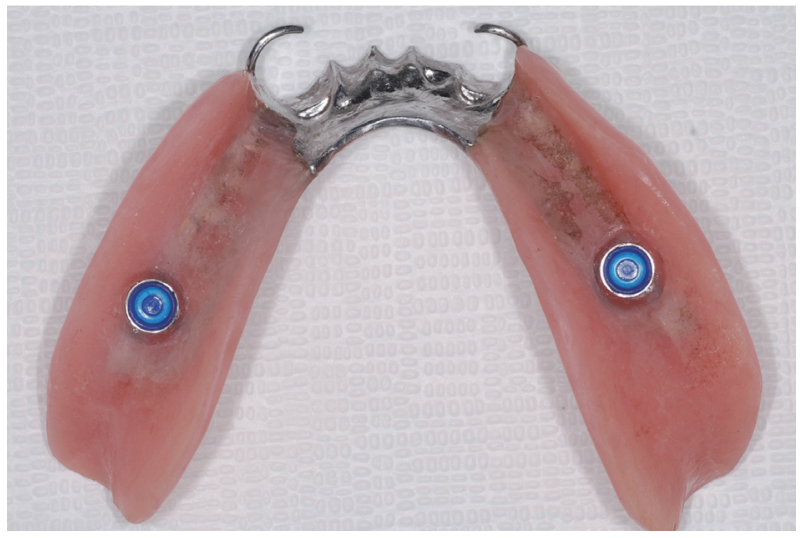

Fig. 8. Old prosthesis was repaired. Blue nylon patrix was inserted.

delivery, the wear of healing abutment was observed. On the basis of studies on displacement and stress distribution of DERPD associated implant attachment, ${ }^{12}$ it is conceivable that the metal framework of denture was repeatedly in contact with healing abutment due to vertical and horizontal movement of the ISRPD during function. In addition, because the healing abutment with a flat head was used, the denture framework was in close contact with the healing abutment, and rotational movement of denture was prevented. It is likely that destructive lateral stress was transferred to the healing abutment. To prevent this problem, a dome shaped abutment that is designed to allow the denture and abutment 1-point contact or allow the denture rotation, is recommended. ${ }^{11}$ In order to obtain support and additional retention from the implant, attachment can be connected. $^{13}$

The attachment might cause slightly more stress on the implant fixture than would be the case with the healing abutment. However, it can prevent friction between the metal structure and surface of healing abutment. And using resilient attachment component such as nylon insert can release the lateral stress by the movement of the RPD. ${ }^{12}$ Attachments can improve the satisfaction of patient for providing adequate retention and reduce the mobility of RPD. ${ }^{5}$ Elsyad et al. ${ }^{14}$ reported that ball and socket attachment decreases the stress around abutment teeth 
but increases the stress around implant due to lack of vertical resiliency. On the other hand, as Locator $^{\circledR}$ attachment can appropriately redistribute the stress between the implant and the abutment teeth for allowing the vertical and horizontal movement of RPD by resilient nylon insert. ${ }^{5}$ In addition, due to its low vertical profile, it effectively reduces the destructive lateral stress around the implant for lowering rotational center. ${ }^{5,15}$ This is supported by Macros et al., who reported less marginal bone loss from implants with locator attachment resulting in better effects on implants. ${ }^{16}$

For preventing the mechanical problem of ISRPD, it is important to select the type of attachment for reducing the lateral stress and excessive contact with the RPD. In addition, it is important to fabricate a precise prosthesis for adaptation. Continuous recall for the fit and occlusion of the denture is necessary. Also, the early signs of mechanical and biological complications, such as mechanical wear of the abutment, require careful observation to ensure good long-term prognosis.

\section{Conclusion}

For preventing the mechanical problem of ISRPD, it is important to select the type of attachment for reducing the lateral stress and excessive contact with the RPD. In addition, continuous recall for the fit and occlusion of the denture is necessary. Also, the early signs of mechanical and biological complications, such as mechanical wear of the abutment, require careful observation to ensure good long-term prognosis.

\section{ORCID}

Jung-Yun Choi http://orcid.org/0000-0002-48499635

Jung-Jin Lee http://orcid.org/0000-0002-7381-5230

Kwang-Yeob Song http://orcid.org/0000-00034283-1278

Ju-Mi Park http://orcid.org/0000-0003-1910-1525

Kyoung-A Kim http://orcid.org/0000-0002-29235351
Jae-Min Seo http://orcid.org/0000-0001-5095-4046

\section{References}

1. Kratochvil FJ, Caputo AA. Photoelastic analysis of pressure on teeth and bone supporting removable partial dentures. J Prosthet Dent 1974;32:52-61.

2. Shahmiri R, Aarts JM, Bennani V, Das R, Swain MV. Strain distribution in a Kennedy Class I implant assisted removable partial denture under various loading conditions. Int J Dent 2013;2013: 351279 .

3. Kuzmanovic DV, Payne AG, Purton DG. Distal implants to modify the Kennedy classification of a removable partial denture: a clinical report. J Prosthet Dent 2004;92:8-11.

4. Wismeijer D, Tawse-Smith A, Payne AG. Multicentre prospective evaluation of implant-assisted mandibular bilateral distal extension removable partial dentures: patient satisfaction. Clin Oral Implants Res 2013;24:20-7.

5. Chikunov I, Doan P, Vahidi F. Implant-retained partial overdenture with resilient attachments. J Prosthodont 2008;17:141-8.

6. Ohkubo C, Kobayashi M, Suzuki Y, Hosoi T. Effect of implant support on distal-extension removable partial dentures: in vivo assessment. Int J Oral Maxillofac Implants 2008;23:1095-101.

7. de Freitas RF, de Carvalho Dias K, da Fonte Porto Carreiro A, Barbosa GA, Ferreira MA. Mandibular implant-supported removable partial denture with distal extension: a systematic review. J Oral Rehabil 2012;39:791-8.

8. McGarry TJ, Nimmo A, Skiba JF, Ahlstrom RH, Smith CR, Koumjian JH, Arbree NS. Classification system for partial edentulism. J Prosthodont 2002;11:181-93.

9. Cunha LD, Pellizzer EP, Verri FR, Pereira JA. Evaluation of the influence of location of osseointegrated implants associated with mandibular removable partial dentures. Implant Dent 2008;17:278-87.

10. Verri FR, Pellizzer EP, Rocha EP, Pereira JA. Influence of length and diameter of implants associated with distal extension removable partial dentures. Implant Dent 2007;16:270-80. 
11. Mitrani R, Brudvik JS, Phillips KM. Posterior implants for distal extension removable prostheses: a retrospective study. Int J Periodontics Restorative Dent 2003;23:353-9.

12. Pellizzer EP, Verri FR, Falcón-Antenucci RM, Goiato MC, Gennari Filho H. Evaluation of different retention systems on a distal extension removable partial denture associated with an osseointegrated implant. J Craniofac Surg 2010;21:727-34.

13. Grossmann Y, Nissan J, Levin L. Clinical effectiveness of implant-supported removable partial dentures: a review of the literature and retrospective case evaluation. J Oral Maxillofac Surg 2009;67: 1941-6.

14. ELsyad MA, Omran AO, Fouad MM. Strains around abutment teeth with different attachments used for implant-assisted distal extension partial overdentures: an in vitro study. J Prosthodont 2015 Sep 29. doi: 10.1111/jopr.12370. [Epub ahead of print]

15. el Charkawi HG, Zekry KA, el Wakad MT. Stress analysis of different osseointegrated implants supporting a distal extension prosthesis. J Prosthet Dent 1994;72:614-22.

16. Mahrous AI, Aldawash HA, Soliman TA, Banasr FH, Abdelwahed A. Implant supported distal extension over denture retained by two types of attachments. A comparative radiographic study by cone beam computed tomography. J Int Oral Health 2015;7:5-10. 


\section{양측성 후방연장 임플란트 보조 국소의치의 합병증과 관리: 증례보고}

\section{최정윤 ${ }^{1}$, 이정진 ${ }^{1}$, 송광엽 ${ }^{1}$, 박주미 ${ }^{1}$, 김경아 ${ }^{2}$, 서재민 ${ }^{1 *}$}

${ }^{1}$ 전북대학교 치의학전문대학원 치과보철학교실 및 구강생체과학연구소

${ }^{2}$ 을지대학교 의과대학 치과학교실

임플란트를 이용한 임플란트 지지 국소의치(Implant supported removable partial denture)는 기존 가철성 국소의치의 생체역학적 한계를 보완할 수 있어 무치악 환자의 유용한 치료로 활용된다. 기계적, 생물학적 합병증을 예방하고 장기간 적절한 예후를 위해서는 정기적인 내원을 통한 관리가 매우 중요하다. 본 증례보고에서 치유 지대주를 이용한 양측성 후 방연장 임플란트 지지 국소의치에서 발생한 기계적 합병증 및 관리에 대해 기술하고자 한다. 임플란트 국소의치 장착 36 개월 후 치유 지대주의 마모 및 파절이 발생하였고, 이에 임플란트 유지 국소의치로 전환하기 위하여 임플란트의 치유 지 대주를 Locator ${ }^{\circledR}$ 로 교체하였다. 환자는 기능 및 심미적으로 만족할 만한 결과를 얻었기에 이를 보고하는 바이다.

(구강회복응용과학지 2016;32(4):338-44)

주요어: 임플란트 지지 국소의치; Locator; 치유 지대주; 임플란트

*교신저자: 서재민

(54896) 전북 전주시 덕진구 백제대로 567 전북대학교 치의학전문대학원 치과보철학교실 및 구강생체과학연구소

Tel: 063-250-2696 | Fax: 063-250-2218 | E-mail: jmseo@jbnu. ac. kr

접수일: 2016년 9월 7일 | 수정일: 2016년 12월 12일 | 채택일: 2016년 12월 17일 